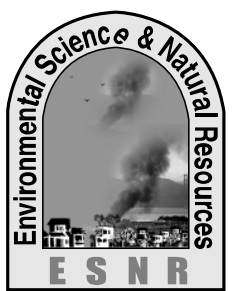

\title{
Prospects of Commercial Date Plum Cultivation in the Environmental Settings of Bangladesh
}

\author{
M. N. H. Khan* and M. R. Hassan \\ Department of Environmental Science and Engineering, \\ Jatiya Kabi Kazi Nazrul Islam University, Trishal, Mymensingh - 2220, Bangladesh \\ *Corresponding author: hasannakibk@gmail.com
}

\begin{abstract}
Agriculture is the single largest producing sector of the economy in Bangladesh. It has a big opportunity to cultivate commercial varieties of Date in the agriculture sector where rice, potato, pulses, wheat etc. are the principal food crops. The present study was conducted to find out the prospects of commercial Date cultivation in the environment of Bangladesh. Date palms are distributed between $10^{\circ} \mathrm{N}$ and $39^{\circ} \mathrm{N}$ latitude in the northern hemisphere. Date palms require an arid climate with an average temperature between $25^{\circ} \mathrm{C}$ to $32^{\circ} \mathrm{C}$ and a sufficient water supply. The environment of Bangladesh complies with the climatic factors in the various date growing areas in the world.
\end{abstract}

Key words: Bangladesh, Cultivation, Date plum, Environment

\section{Introduction}

Agriculture is the single largest producing sector of the economy and contributes about $17.22 \%$ to the total Gross Domestic Product (GDP) in Bangladesh (BBS, 2016). GDP growth rate of Bangladesh mainly depends on the performance of the agriculture sector. Rice, jute, sugarcane, potato, pulses, wheat, tea and tobacco are the principal crops of Bangladesh (BBS, 2016). There is a big opportunity to cultivate commercial varieties of Date in the agriculture sector of Bangladesh.

Date plum (Phoenix dactylifera L.) of the family Arecaceae is a key plantation crop of many countries of arid regions of West Asia and North Africa (AlKhalifah et al., 2012). Dates are produced in the hot arid regions of the world and marketed worldwide as high value confectionary (Mahmoudi et al., 2008). The current geographic distribution of date plum encompasses the dry desert regions of the world between $10^{\circ} \mathrm{N}$ and $39^{\circ} \mathrm{N}$ in the Northern hemisphere and between $5^{0} \mathrm{~S}$ to $33^{0} 51^{\prime} \mathrm{S}$ in the Southern hemisphere (Al-Khalifah et al., 2012).

With the present uncertainty in the world food supply and the expected increase in demand, the date palm could be a good source of food of high nutritional value. Lot of food products are produced from Date due to its high nutritional values. The commercial cultivation of Date in Bangladesh would meet the demand of food as well as give a good account for the economic growth of the country. The present study was conducted to find out the prospects of commercial Date cultivation in the environment of Bangladesh.

\section{Origin and classification of date palm}

Date Palm (Phoenix dactylifera L.) is thought to have originated in Mesopotamia (what is now Iraq) and its cultivation spread to the Arabian Peninsula, North Africa, and the Middle Eastern Countries in ancient times (about 5000 years ago) (Zaid and de Wet, 2002a). Belonging to the Angiosperms-Monocotyledones, Palmaceae is a family of about 200 genera and 1, 500 species (Dowson, 1982). Phoenix (Coryphoideae Phoeniceae) is one of the genera which contains a dozen species, all native to the tropical or subtropical regions of Africa or Southern Asia, including Phoenix dactylifera L. (Munier, 1973). According to Dransfield and Uhl (1986) date palm is classified as follows:

Group: Spadiciflora

Order: $\quad$ Palmea

Family: Palmaceae

Sub-family: Coryphyoideae

Tribe: Phoeniceae

Genus: Phoenix

Species: Dactylifera $L$.

According to Chevalier (1952) among the first listed twelve species of the genus "Phoenix", along with their geographical distribution, P. acaulis Roxb and P. paludosa Roxb are found in Bangladesh.

\section{Geographical distribution of date palm}

Date palm is found in both the Old World (Near East and North Africa) and the New World (American continent) where dates are grown commercially in large quantities (Zaid and de Wet, 2002b). In order to have a clear picture on the geographical distribution of date palm, it is worth looking at it from the following aspects: (i) Distribution according to latitude and (ii) Distribution according to altitude.

\section{Distribution according to latitude}

The distribution according to latitude for both northern and southern hemispheres is illustrated in Tables 1. The extreme limits of date palm distribution are between $10^{\circ} \mathrm{N}$ (Somalia) and $39^{\circ} \mathrm{N}$ (Elche/Spain or Turkmenistan). Favorable areas are located between $24^{\circ}$ and $34^{\circ} \mathrm{N}$ (Morocco, Algeria, Tunisia, Libya, Israel, Egypt, Iraq, Iran, etc.). In USA, date palm is found between $33^{\circ}$ and $35^{\circ} \mathrm{N}$. Because of climatic factors, the date palm will grow, but will not fruit properly outside the above defined geographical limits. In Asia, $32^{\circ} \mathrm{N}$, in the Indus Valley, is the northern limit of date palm cultivation (Zaid and de Wet, 2002b). 
Table 1. Latitude limits of date palm cultivation in the Northern and the southern hemisphere

\begin{tabular}{|l|r|l|r|}
\hline Country & Latitude & Country & Latitude \\
\hline Pakistan & $25^{\circ} 22^{\prime} \mathrm{N}$ to $33^{\circ} \mathrm{N}$ & Arabian Peninsula & $12^{\circ} 36^{\prime} \mathrm{N}$ to $23^{\circ} 37^{\prime} \mathrm{N}$ \\
\hline India & $23^{\circ} \mathrm{N}$ to $25^{\circ} 59^{\prime} \mathrm{N}$ & Somalia & $1^{\circ} 47^{\prime} \mathrm{N}$ \\
\hline Iran & $28^{\circ} 18^{\prime} \mathrm{N}$ to $34^{\circ} 31^{\prime} \mathrm{N}$ & Djibouti & $11^{\circ} 30^{\prime} \mathrm{N}$ \\
\hline Turkmenistan & $29^{\circ} 07^{\prime} \mathrm{N}$ to $39^{\circ} \mathrm{N}$ & Ethiopia & $10^{\circ} 15^{\prime} \mathrm{N}$ \\
\hline Iraq & $30^{\circ} 34^{\prime} \mathrm{N}$ to $34^{\circ} 53^{\prime} \mathrm{N}$ & Sudan & $15^{\circ} 02^{\prime} \mathrm{N}$ \\
\hline Syria & $34^{\circ} 27^{\prime} \mathrm{N}$ to $35^{\circ} 27^{\prime} \mathrm{N}$ & Cameroon & $8^{\circ} 40^{\prime} \mathrm{N}$ \\
\hline Palestine, Israel and Lebanon & $30^{\circ} \mathrm{N}$ to $34^{\circ} 26^{\prime} \mathrm{N}$ & Chad & $13^{\circ} 40^{\prime} \mathrm{N}$ \\
\hline Cyprus and Turkey & $36^{\circ} 10^{\prime} \mathrm{N}$ to $36^{\circ} 34^{\prime} \mathrm{N}$ & Niger & $13^{\circ} 45^{\prime} \mathrm{N}$ to $18^{\circ} 50^{\prime} \mathrm{N}$ \\
\hline Algeria & $33^{\circ} 09^{\prime} \mathrm{N}$ to $35^{\circ} 14^{\prime} \mathrm{N}$ & Mauritania & $16^{\circ} 50^{\prime} \mathrm{N}$ to $20^{\circ} 38^{\prime} \mathrm{N}$ \\
\hline Spain & $38^{\circ} 17^{\prime} \mathrm{N}$ & Mali & $13^{\circ} 20^{\prime} \mathrm{N}$ to $18^{\circ} 27^{\prime} \mathrm{N}$ \\
\hline Egypt & $30^{\circ} 02^{\prime} \mathrm{N}$ & Senegal & $14^{\circ} 51^{\prime} \mathrm{N}$ \\
\hline Tunisia & $33^{\circ} 57^{\prime} \mathrm{N}$ & Tanzania R.S.A.) & $5^{\circ} \mathrm{S} ; 27^{\circ} \mathrm{S}$ to $29^{\circ} \mathrm{S}$ \\
\hline Morocco & $31^{\circ} 26^{\prime} \mathrm{N}$ & Australia & $25^{\circ} 03^{\prime} \mathrm{S}$ to $33^{\circ} 51^{\prime} \mathrm{S}$ \\
\hline USA & $33^{\circ} 43^{\prime} \mathrm{N}$ & Namibia & $20^{\circ} 09^{\prime} \mathrm{S}$ to $28^{\circ} 24^{\prime} \mathrm{S}$ \\
\hline Source: Zaid
\end{tabular}

Source: Zaid and de Wet, $2002 b$

\section{Distribution according to altitude}

Altitude is very important since it imposes the availability of water and the temperature limits which largely determine the distribution of date palm in the world. In fact, date palm grows and flourishes from $392 \mathrm{~m}$ below sea level to $1,500 \mathrm{~m}$ above with an altitude range of 1,892m (Zaid and de Wet, 2002b).

\section{Climatic requirements of date palm}

The climatic factors influence in date growth and production. Temperature, rainfall, humidity, light and wind are the most important climatic factors which determine the suitability of a specific site for growing date palm.

\section{Temperature}

The highest maximum temperatures found in the date growing areas of the world are the result of low humidity, great insolation and long days in summer. Exceptional high temperatures $\left( \pm 56^{\circ} \mathrm{C}\right)$ are well endured by a date palm for several days under irrigation. During winters, temperatures below $0^{\circ} \mathrm{C}$ are also endured. The zero vegetation point of a date palm is $7^{\circ} \mathrm{C}$, above this level growth is active and reaches its optimum at about $32^{\circ} \mathrm{C}$; the growth will continue at a stable rate until the temperature reaches $38^{\circ} \mathrm{C} / 40^{\circ} \mathrm{C}$ when it will start decreasing (Zaid and de Wet, 2002c). According to Mason (1925), the growth of a date palm does not cease if, (i) minimum daily temperature does not fall below freezing point, and (ii) maximum daily temperature at the growth centre does not fall below 9 to $10^{\circ} \mathrm{C}$. The temperature requirements presented in the Table 2 are those of normal growth, flowering and fruit maturation.

Table 2. Maximum, minimum and average temperatures of various date growing areas

\begin{tabular}{|c|c|c|c|c|}
\hline Station/Country & $\begin{array}{c}\text { Length of record } \\
\text { (years) }\end{array}$ & $\begin{array}{c}\text { Maximum } \\
\text { May to Oct. }\end{array}$ & $\begin{array}{c}\text { Minimum } \\
\text { (Jan.) }\end{array}$ & Average \\
\hline Turbat/Pakistan & & 41 & 6.7 & \\
\hline Basra/Iraq & 19 & 37.4 & 6.4 & 24.2 \\
\hline Muscat/Saudi Arabia & & 38.5 & 15.9 & \\
\hline Cairo/Egypt & & 33.7 & 7.6 & \\
\hline Gabes/Tunisia & 30 & 29.3 & 6 & 21.3 \\
\hline Touggourt/Algeria & 15 & 35.9 & 3.4 & 21.4 \\
\hline Erfoud/Morocco & 12 & 36.4 & 1.3 & \\
\hline Elche/Spain & & 28.2 & 6.9 & \\
\hline Indio/California; USA & 25 & 37.6 & 3.7 & \\
\hline Bahrein/Bahrein & 12 & 34.3 & 13.3 & \\
\hline Oued Haifa/Sudan & 30 & 40.2 & 1.1 & \\
\hline Keetmanshoop/Namibia & 37 & $35.1(\mathrm{Jan})$ & 6.2 (July) & 20.7 \\
\hline
\end{tabular}

Source: Al Bakr, 1972 and Dowson, 1982.

\section{Rainfall}

Date palm culture has mostly been developed in areas with winter rainfall which does not cause harm to the date fruits. Table 3 shows that the main date-growing regions are almost rainless until November. Rain during the flowering and harvest season is likely to cause some damage to the fruits. The major damage caused by rain occurs when either the rain is early, or the dates are late in ripening. In fact, rain does not seriously damage the dates when they are still at the early Khalal stage, but 
rather has a beneficial effect by washing away all dust

2002c). and sand particles from the fruits (Zaid and de Wet,

Table 3. Rainfall in the main date palm growing regions

\begin{tabular}{|c|c|c|c|c|c|c|}
\hline Grove/Country & Length of record (years) & & & infall $(1$ & & \\
\hline Northern Hemisphere & & Jul. & Aug. & Sept. & Oct. & Nov. \\
\hline Multan/Pakistan & - & 60 & 50 & 8 & 0 & 2 \\
\hline Maskat/Oman & 37 & 0 & 0 & 0 & 2 & 10 \\
\hline Bushire/Iran & 52 & 0 & 0 & 0 & 2 & 40 \\
\hline Bahrein/Bahrein & 21 & 0 & 0 & 0 & 0 & 10 \\
\hline Basra/Iraq & 24 & 0 & 0 & 0 & 2 & 22 \\
\hline Cairo/Egypt & 25 & 0 & 0 & 0 & 1 & 3 \\
\hline Tozeur/Tunisia & 49 & 1 & 2 & 7 & 9 & 12 \\
\hline El Oued/Algeria & 25 & 0 & 0 & 3 & 7 & 13 \\
\hline Biskra/Algeria & 25 & 1 & 2 & 7 & 9 & 12 \\
\hline Indio, $\mathrm{Ca} / \mathrm{USA}$ & 33 & 0 & 1 & 1 & 1 & 1 \\
\hline Yuma, Ariz/USA & 60 & 1 & 2 & 1 & 1 & 1 \\
\hline Southern Hemisphere & & Jan. & Feb. & Mar. & Apr. & May \\
\hline Alice Springs/Australia & 17 & 43 & 41 & 33 & 16 & 13 \\
\hline Finke/Australia & 26 & 22 & 40 & 17 & 14 & 11 \\
\hline Keetmanshoop/Namibia & 37 & 25.2 & 43.4 & 41.3 & 16.3 & 4.4 \\
\hline Mariental/Namibia & 50 & 35.9 & 54.5 & 47.2 & 15.7 & 3.1 \\
\hline
\end{tabular}

Source: Nixon and Carpenter, 1978; Dowson, 1982; and McColl, 1992.

\section{Relative humidity}

Depending on air humidity at the locality of a date palm plantation, various advantages and/or disadvantages are found. In fact, the date palm eco-system is mostly of an arid nature where air relative humidity has a large influence (Zaid and de Wet, 2002c). Air humidity also affects the date quality during the maturation process.
At high humidity, fruits become soft and sticky, while at low humidity they become very dry (case of Northern Sudan and in-land plantations) (Zaid and de Wet, 2002c). Table 4 illustrates the high relative humidity of four Middle East date plantations and at one place in Namibia.

Table 4. Examples of relative humidity of various date plantations

\begin{tabular}{|l|c|c|c|c|c|}
\hline Place/Country & Length of record (years) & \multicolumn{4}{|c|}{ Averages of Relative Humidity (\%) } \\
\hline & & July & August & September & October \\
\hline Baghdad/Iraq & 80 & 37 & 40 & 42 & 51 \\
\hline Basra/Iraq & 18 & 51 & 51 & 55 & 60 \\
\hline Bahrein/Bahrein & 15 & 68 & 74 & 74 & 77 \\
\hline D.I. Khan/Iran & 10 & 72 & 75 & 75 & 76 \\
\hline & & Jan. & Feb. & March & April \\
\hline Keetmanshoop/Namibia & 37 & 43 & 52 & 57 & 58 \\
\hline
\end{tabular}

\section{Source: Dowson, 1982.}

\section{Geography and climate of Bangladesh}

Bangladesh lies in the north eastern part of South Asia between $20^{\circ} 34^{\prime}$ and $26^{\circ} 38^{\prime}$ north latitude and $88^{\circ} 01^{\prime}$ and $92^{\circ} 41^{\prime}$ east longitude. Bangladesh enjoys generally a sub-tropical monsoon climate. In winter there is not usually much fluctuation in temperature which ranges from minimum of $77^{0} \mathrm{C}-13^{\circ} \mathrm{C}$ to maximum $24^{0} \mathrm{C}-31$ ${ }^{0} \mathrm{C}$ (Fig 1). The maximum temperature recorded in summer is $37^{\circ} \mathrm{C}$ although in some places this occasionally rises up to $41^{\circ} \mathrm{C}$ or more. The period of Monsoon is accounts for $80 \%$ of the total rainfall. The average annual rainfall varies from 1429 to 4338 millimeters (Fig 2). Comparing to the geography and environmental conditions for Date cultivation in the world and Bangladesh, it can be easily said that it is very much suitable for the cultivation of commercially important varieties in Bangladesh.

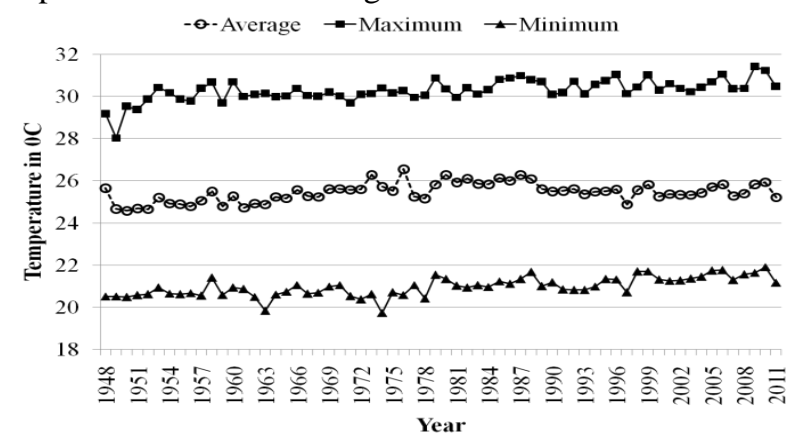

Fig. 1. Average, minimum and maximum temperature in Bangladesh from 1948 to 2011 


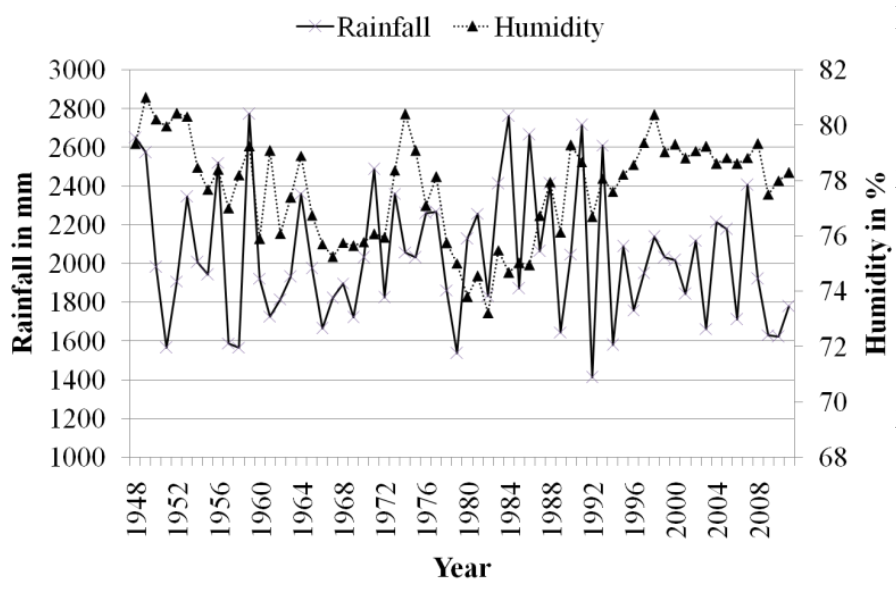

Fig. 2. Yearly total Rainfall and average Relative Humidity in Bangladesh from 1948 to 2011

\section{Conclusions}

The date palm could play an important role in the ecology of various desert and semi-desert environments. This Date plum could also be cultivated in the environmental context of Bangladesh where the geography and climate matches the other Date growing countries in the world. Furthermore, with the micro climate created by date palm plantations, the cultivation of some fruit palms and annual crops will be possible.

\section{References}

Al-Bekr, A. J. 1972. The Date Palm: A review of its past, present status and the recent advances in its culture industry and trade. Iraq (Arabic), 1085pp.

Al-Khalifah, N. S.; Askari, E. and Shanavaskhan A. E. 2012, Date Plam Tissue Culture and Genetical Identification of Cultivars Grown in Saudi Arabia, National Center for Agriculture Technologies, King Abdulaziz City for Science and Technology, Riyadh, 264p.

BBS. 2016. Bangladesh Bureau of Statistics, Statistics Division, Ministry of Planning, Statistical Year Book of Bangladesh-2014, BBS, Dhaka, Bangladesh.

Chevalier, A. 1952. Recherche surles Phoenix africains; R. B. A., Mai-Juin.

Dowson, V. H. W. 1982, Date production and protection with special reference to North Africa and the Near East. FAO Technical Bulletin No. 35. pp 294.

Dransfield, J. and Uhl, N. W. 1986, An outline of a classification of palms. Principles, 30 (1):3-11.

Mahmoudi, H. G.; Hosseininia, H.; Azadi and Fatemi, M. 2008. Enhancing date palm processing, marketing and pset control through organic culture. J. Organic Systems, 3(2):29-39.

McColl, C. R. 1992. Central Australian Date Industry, a Strategy for Development. Technical Bulletin No. 186. Northern Territory of Australia. 29pp.

Munier, P. 1973. Le Palmier-dattier-Techniques agricoles et productions tropicales; Maison Neuve et Larose, 217pp; Paris.
Nixon, R. W. and Carpenter, J. B. 1978. Growing Dates in the United States. U. S. Dept. of Agriculture, Agric. Information Bulletin No. 207: USDA. Technical Document, 63 pp.

$\therefore$ Zaid, A. and de Wet, P. F. 2002a. Botanical and Systematic Description of the Date Palm. In: Zaid A. ed. Date Palm Cultivation, FAO Plant Production and Protection Paper, 156 Rev. 1, Food and Agricultural Organization of the United Nations, Rome.

Zaid, A. and de Wet, P. F. 2002b. Origin, Geographical Distribution and Nutritional Values of Date Palm. In: Zaid A. ed. Date Palm Cultivation, FAO Plant Production and Protection Paper, 156 Rev. 1, Food and Agricultural Organization of the United Nations, Rome.

Zaid, A. and de Wet, P. F. 2002c. Climatic Requirements of Date Palm. In: Zaid A. ed. Date Palm Cultivation, FAO Plant Production and Protection Paper, 156 Rev. 1, Food and Agricultural Organization of the United Nations, Rome. 